\title{
Homoseksualność według starożytnych Greków
}

\author{
Homosexuality According to the Ancient Greeks
}

\section{ŁUKASZ LASKOWSKI}

Wyższe Seminarium Duchowne Archidiecezji Częstochowskiej luca.laskowski@gmail.com, ORCID: 0000-0002-0087-300X

\begin{abstract}
Streszczenie: Artykuł przedstawia problem homoseksualności w starożytnej Grecji. Paiderastia jako relacja między dorosłym mężczyzną i chłopcem to szczególny element wychowania. Niekiedy wiąże się z opresją seksualną i natarczywością właściwą społeczeństwu patriarchalnemu. Relacje homoseksualne między rówieśnikami i dorosłymi były znane i akceptowane, o ile nie przekraczały ustalonych przez polis zasad. Nie mogły naruszać cnoty umiaru oraz sprowadzać mężczyzn do roli przypisywanej kobietom, a partner bierny nie mógł odczuwać przyjemności z seksualnej relacji. Kobiety nie mogły przejmować roli męskiej, gdyż oznaczałoby to osiąganie przyjemności właściwej mężczyznom. Przyczyn homoseksualizmu doszukiwano się w pozytywnej woli boga, tłumacząc ją jako pragnienie zjednoczenia się także z tym, co podobne, a także w naturze i wychowaniu, a później w fizjologii człowieka.
\end{abstract}

Słowa kluczowe: homoseksualizm, starożytna Grecja, polis, seks, paideia, paiderastia, Safona, Alkman, Anakreont, Arystofanes, Platon, Ksenofont, Arystoteles, Teokryt

Abstract: The article presents the issue of homosexuality in ancient Greece. Pederasty as a relationship between an adult male and a boy was a special part of mentoring. It is sometimes associated with the sexual oppression and intrusiveness relevant to a patriarchal society. Homosexual relations between peers and adults were known and accepted as long as they did not exceed the rules set by the polis. They could not violate the virtue of moderation and reduce men to the role ascribed to women, and the passive partner did not experience pleasure in the sexual relationship. Women could not take on the male role because it would mean achieving the pleasure inherent in men. The causes of homosexuality were sought in the positive will of god, explaining it as a desire to unite also with what is similar, as well as in nature and upbringing, and later in human physiology.

Keywords: homosexuality, ancient Greece, polis, sex, paideia, pederasty, Sappho, Alcman, Anacreon, Aristophanes, Plato, Xenophon, Aristotle, Theocritus

Badając postawiony w tytule problem trzeba zwrócić uwagę najpierw na sam termin „homoseksualizm”. Ponieważ powstał on w XIX wieku, niektórzy uczeni twierdzą, że nie nadaje się on do opisu zjawisk należących do świata starożytnego ${ }^{1}$. W związku z tym uważają, że lepiej byłoby mówić o homoseksualności². Sygnalizuje się wówczas czytelnikowi, że sięgając po dorobek antyku ma do czynienia ze zgoła odmiennym zjawiskiem od zwyczajów obserwowanych współcześnie. Choć Kenneth J. Dover

1 Nissinen, Homoeroticism in the Biblical World, 57-69.

2 Szeroko na temat terminologii Sieradzan, „Bez paiderasteia nie ma paideia”, 19-22. 
swojej pomnikowej książce nadał tytuł Homoseksualizm grecki i z powodzeniem go bronił ${ }^{3}$, ujmijmy i my tę problematykę ostrożniej, posługując się terminami „homoseksualność” względnie „homoerotyzm”.

Trzeba jednak pamiętać, że starożytni Grecy nie wypracowali jednolitego podejścia do homoseksualności. Platon pisał, że

w Elidzie i u Beotów, i tam, gdzie nikt porządnie mówić nie umie, prawo powiada po prostu, że oddawać się miłośnikom jest rzeczą dobrą i nikt, ani młody, ani stary nie śmiałby powiedzieć, że to coś złego; ale z pewnością dlatego tylko, żeby nie mieli kłopotu, gdyby który próbował słowami młodych ludzi uwodzić; oni przecież nie umieją mówić. W Jonii natomiast i wielu innych stronach uważają to za zbrodnię: tam, gdzie barbarzyńskie ludy mieszkają. Naturalnie, dla barbarzyńców to jest zbrodnia, podobnie jak filozofia i zamiłowanie do gimnastyki ${ }^{4}$.

Należy również zauważyć, że zachowane teksty to w przeważającej mierze opisy relacji między mężczyznami. Świadectwa dotyczące kobiet pojawiają się rzadko, co stawia badaczy w trudnej sytuacji i każe skoncentrować się na stosunkowo enigmatycznych przekazach, pojawiających się głównie w poezji. Istnieje również szereg zabytków ikonograficznych, które zawierają motywy homoerotyczne dotyczące mężczyzn, a tylko wyjątkowo kobiet ${ }^{5}$. Grecy bowiem bez skrępowania ozdabiali ceramikę scenami seksualnymi. Mają one charakter zarówno mitologiczny, jak i społeczny, często żartobliwy i frywolny, dla współczesnego człowieka niekiedy nawet pornograficzny ${ }^{6}$. Do niektórych z tych zabytków odwołamy się jako do źródeł pomocniczych.

Temat homoseksualności był i jest szeroko dyskutowany․ Badacze początkowo wskazywali, że świat homerycki był jeszcze pozbawiony tego fenomenu. Późniejsze analizy wykazały, że jest to obserwacja pobieżna, oparta przede wszystkim na argumencie z milczenia, dziś nie do utrzymania. Erich Bethe, szukając źródeł i najpierwszych świadectw, zwrócił uwagę na Dorów. Ich wojskowe, spartańskie wychowanie zdaje się bowiem sprzyjać miłości do chłopców - paiderastii, w zakresie Erosa homoseksualnego najszerzej znanej ${ }^{8}$. Co prawda na Krecie zachowały się doryckie inskrypcje zdające się potwierdzać tę teorię, lecz rozbieżność świadectw nie

\footnotetext{
Lengauer, „Eros, polis, obywatel”, 130.

Plato, Symposium 182 B-C (Platon, Dialogi, 82).

Kenneth J. Dover (Homoseksualizm, 209, 273) odnosi się do attyckiej wazy czerwonofigurowej (R207), na której kobieta pieści drugą kobietę; nazywa wazę zupełnie wyjątkową.

6 Dopiero w III wieku n.e. Atenajos pierwszy użył słowa pornografia, gdy opisywał artystów malujących

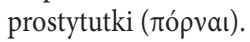

7 Analizę wyników badań praktycznie do końca XX wieku przedstawił Włodzimierz Lengauer („Od haniebnego występku").

8 Bethe, „Die dorische Knabenliebe”, 438-475.
} 
pozwala na wyciągnięcie ostatecznych wniosków9 . Tak więc uczeni początkowo badali homoseksualność grecką w zakresie paiderastii, widząc w niej element systemu wychowania wojskowego, a następnie także inicjacji w życie obywatelskie ${ }^{10}$. Kamieniem milowym była wspomniana już książka Dovera Homoseksualizm grecki (1978, wyd. polskie 2004), która przyniosła nowe, rozszerzone o kwestie antropologiczno-kulturowe, spojrzenie na problem. Jednakże dopiero Michel Foucault ${ }^{11}$ swoją Historią seksualności (1976, 1984, wyd. polskie 1995) zwrócił uwagę na to, że seksualność ludzka jest także działaniem, które każda wspólnota ujmuje w swoim wyjątkowym kontekście. Określa zarazem, które zachowania są dopuszczalne, a które nie do przyjęcia. To przede wszystkim dzięki tej pracy Eros homoseksualny stał się przedmiotem zainteresowania historyków. Lata 80 . XX wieku przyniosły rozwój badań nad społecznym uwarunkowaniem roli płci (gender studies). Eva C. Keuls w pracy o znaczącym tytule The Reign of the Phallus [Królestwo fallusa] (1985) dostrzegła i doceniła rolę przywódczą dojrzałych mężczyzn w Atenach. Doszła do wniosku, że działalność seksualna mężczyzn była jednym z przejawów ich władzy w polis. Autorka zamieszcza liczne i cenne świadectwa ikonograficzne. Śladem Keuls poszedł J. Winkler, badając w książce The Constraints of Desire (1990) zależność między płcią i rolą społeczną w greckiej polis. Trzeba również przywołać uzasadniony postulat, który wysunęła włoska badaczka antyku klasycznego Eva Cantarella, autorka książki na temat biseksualizmu w Grecji i Rzymie. Według niej również w zakresie Erosa homoseksualnego najczęściej chodziłoby o zachowania biseksualne ${ }^{12}$. Ostatnie lata przyniosły edycję przekładów tekstów źródłowych dla poruszanego tu problemu Homosexuality in Greece and Rome. A Sourcebook of Basic Documents (2003), opracowaną przez Thomasa H. Hubbarda, oraz szereg szczegółowych artykułów, stanowiący bogactwo materiału, który w najistotniejszym zakresie trzeba przywołać w aparacie naukowym.

Podejście samych Greków do miłości wymaga zatem uwagi i zastosowania sławnej maksymy Tacyta: sine ira et studio. Poniżej w kilku etapach nakreślimy główne zagadnienia związane $\mathrm{z}$ homoseksualnością. Wychodząc od wychowania przez inne sposoby jej wyrażania i oceny autorstwa samych Greków, dojdziemy do antycznych refleksji na temat jej pochodzenia i siły. Nazwiska tłumaczy tekstów źródłowych czytelnik znajdzie w bibliografii.

\footnotetext{
Lengauer, „Od haniebnego występku”, 317.

10 B. Sergent, L'homosexualité initiatique dans l'Europe ancienne. Książkę tę poprzedza jego L'homosexualité dans la mythologie grecque.

11 Tom II (Użytek z przyjemności), to nasycona faktografią pozycja, ważna dla podejmowanego tu tematu.

12 Cantarella, Selon la nature.
} 


\section{Paiderastia}

W ramach greckiego wychowania, zwanego paideia, funkcjonowała miłość do wy-

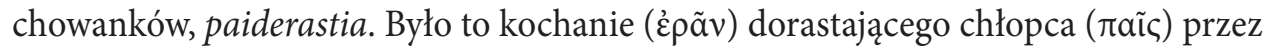
mężczyznę-obywatela. Strony tej relacji literatura przedmiotu opisuje terminami eromenos (dosł. „ukochany”, pojęcie dotyczy młodzieńca) i erastes („kochający”, był nim dorosły $)^{13}$. Instytucja ta była ściśle regulowana prawami tradycji i zwyczaju. Wychowywano pełnego propaństwowych cnót obywatela, a jednocześnie dzielnego i wstrzemięźliwego wojownika. To dzięki zaznanej wtedy miłości młody człowiek miał nauczyć się postępować szlachetnie oraz stawiać czoło wrogowi w walce. Taką rolę Erosa homoseksualnego docenił i przedstawił w języku swej filozofii Platon ${ }^{14}$, a praktycznie wykorzystali Beoci, powołując do życia Święty Zastęp złożony wyłącznie z mężczyzn pozostających w relacjach miłosnych ${ }^{15}$.

Erastes musiał być pełnoprawnym obywatelem, więc zarazem pełnoletnim ${ }^{16}$. Nie był jednak ograniczony zaawansowanym wiekiem. Niektóre świadectwa podkreślają, że miłość do chłopców rozpalała serca także starszych mężczyzn. Z epoki archaicznej pochodzi enkomion Pindara (fr. 123) na cześć Theoksenosa z Tenedos, który był jego eromenosem; według Księgi Suda osiemdziesięcioletni poeta miał umrzeć w jego ramionach ${ }^{17}$. Podobnie było w epoce klasycznej. W relacjach $\mathrm{z}$ dwóch spraw sądowych zachowały się interesujące wzmianki na ten temat. Dwaj obywatele w średnim wieku oświadczają wobec sędziów, że oni również się zakochują, choć są statecznymi mężami i ojcami. Pierwszy z nich to Ajschynes. Oskarżając Timarchosa o nieobyczajne zachowania, nie chciał uchodzić za barbarzyńcę gardzącego paiderastią. Zarzekał się więc, że i jemu zdarza się zakochiwać w chłopcach, choć jest już człowiekiem czterdziestopięcioletnim. Druga postać to nieznany z imienia Ateńczyk. Bronił się przed sądem mową napisaną dla niego przez Lizjasza, a sprawa dotyczyła pobicia i zranienia współobywatela imieniem Simon. Przyczyną sporu był Eros. Obaj panowie poszli bowiem w konkury do tego samego chłopaka. Sprawy te są świadectwem istnienia społecznie powszechnie akceptowanego zwyczaju wchodzenia w relacje miłosne

13 Na ten temat np. Dover, Homoseksualizm, 27-19.

14 Plato, Symposium 178 C-D (Platon, Dialogi, 79): „Otóż powiadam, że kiedy człowiek kocha, a wyda się jakiś jego szpetny postępek albo się pokaże, że się dał użyć do jakiejś podłej rzeczy, bo się nie bronił przez swoje tchórzostwo, wtedy najgorzej człowieka boli, gdy go oblubieniec zobaczy; wolałby już, żeby go widział ojciec albo przyjaciele, albo ktokolwiek inny. Podobnie widzimy, że i oblubieńcy wstydzą się najwięcej swoich miłośników, kiedy się który da przychwycić na jakim łotrostwie. Więc, gdyby to można było stworzyć państwo lub wojsko złożone z miłośników i oblubieńców, z pewnością nie znaleźliby lepszego pierwiastka porządku społecznego, jak wzajemne powstrzymywanie się od postępków złych, chęć odznaczenia się w oczach drugiego i współzawodnictwo wzajemne. Tacy, choćby ich mało było, zwyciężyliby, powiem, cały świat." 
mężczyzn w średnim wieku z młodymi chłopcami ${ }^{18}$. Nieustanne zaś zakochiwanie się jest pośrednim świadectwem na to, że Eros paiderastyczny nie oznaczał związków ani trwałych, ani monogamicznych.

Odmienną formę paiderastii, prawdopodobnie najstarszą uwzględnioną w prawodawstwie polis, wypracowali Lacedemończycy. Również tu każdy dorosły obywatel mógł pełnić rolę wychowawczą. Ksenofont nadmienił, że Spartanie „uważają, że ten, kto pożąda ciała innego mężczyzny, nie potrafi dokonać żadnego dobrego i chwalebnego czynu" ${ }^{19}$. Czynnikiem kształtującym młodzież miała być zatem miłość na wzór rodzicielskiej bądź braterskiej, ale wzbogacona o karność. Według zaś późnego świadectwa Plutarcha ${ }^{20}$ istniała wspólnota erastesów, która sprawowała nadzór nad młodszymi obywatelami. Nie ma jednak dowodów, żeby w jej ramach podejmowano współżycie seksualne. Z odmienności lacedemońskich tradycji Ateńczycy wyciągali wniosek, że w rzeczywistości Spartanami rządziły ich kobiety ${ }^{21}$. Jest to jednak świadectwo o charakterze anegdotycznym. Omawiając ten temat Włodzimierz Lengauer wnioskuje, że specyfika Sparty polegała na nieobecności w tamtejszej paiderastii miłości „w jej zmysłowym aspekcie”22. Skądinąd jednak wiemy, że niektórzy ze Spartiatów wchodzili w związki uczuciowe z mężczyznami, co nie przeszkadzało im w pełnieniu istotnych ról społecznych.

Uznając paiderastię za instytucję wpisaną w homoseksualność, trzeba zaznaczyć, że ujmowano ją jako miłość między dorosłym mężczyzną i dorastającym chłopcem (do czasu pojawienia się u niego zarostu na twarzy), miłość idealizującą. Łączyła się ona z ryzykiem, ponieważ młodzieniec, wiążąc się z zabiegającym o jego miłość erastesem, mógł dokonać złego wyboru. Jednak powinien podjąć takie ryzyko. Jeśli trafi na mężczyznę wartościowego, wiele zyska. Lecz jeśli uwiódłby go obywatel czyhający tylko na cielesny powab, to - według argumentacji Platona - choć został zwiedziony, nie straci zalet ducha, ponieważ oszukał się pięknie ${ }^{23}$. Doceniając zaś prawość erastesa, Ksenofont chwali jego miłość do młodzieńca o wielkich zaletach ponieważ do wyboru takiego eromenosa zdolny jest tylko odpowiednio szlachetny mężczyzna ${ }^{24}$.

Niebezpieczeństwa paiderastii, leżące w jej związku z erotyką, dostrzegali sami Ateńczycy. Ślady tego dostrzegamy przede wszystkim w okresie klasycznym. Znana jest zapisana przez Ksenofonta sokratejska jeszcze krytyka Kritiasza, który zapałał żądzą do pięknego Eutydema i - co miał mu wprost zarzucić Sokrates - pragnął się

\footnotetext{
18 Lengauer, „Eros Among Citizens”, 81-83; Lengauer, „Od haniebnego występku”, 320.

19 Xenophon, Convivium 8, 35 (Ksenofont, Pisma, 293).

20 Plutarchus, Lycurgus 17, 1.

21 Znana jest historia „o Gorgo, żonie Leonidasa. Oto kiedy jakaś kobieta, zapewne cudzoziemka, powiedziała: «Wy, Lakonki, jako jedyne kobiety władacie mężczyznami», ona odrzekła: «Bowiem tylko my rodzimy prawdziwych mężczyzn»” (za Plutarch, Powiedzenia królów i wodzów, 212).

22 Lengauer, „Od haniebnego występku”, 319.

23 Plato, Symposium 185 A-B (Platon, Dialogi, 85).

24 Xenophon, Convivium 8, 8 (Ksenofont, Pisma, 286).
} 
„otrzeć o niego jak świnia o kamień”25. Ta złośliwa uwaga stała się kamieniem węgielnym wrogości Kritiasza do filozofa. Platon początkowo akceptował paiderastię połączoną ze zmysłowym aspektem miłości. Później jednak wycofał się z tego stanowiska. Platoński Sokrates ${ }^{26}$, kuszony przez ślicznego Alkibiadesa, miał spać z nim pod jednym płaszczem jak z własnym synem, co pijany piękniś ze zdziwieniem wyznaje na uczcie u Agatona ${ }^{27}$. Ostatecznie filozof odrzuca dotychczasowe zwyczaje i pisze, że „wolno kochać i obcować z kochankiem, i dotykać go jak syna"28. Tak wysokie wymagania nie były zapewne zbyt popularne, skoro prawie pół tysiąca lat później Lukian z Samosat wyznaje ustami Lykinosa, że „miłość chłopięca, która ma na celu święte prawa przyjaźni, jest dziełem jedynie filozofii. Dlatego wszyscy powinni wstępować w związki małżeńskie, ale mędrcom należy zostawić kochanie chłopców”29.

Paiderastia była miłością niesymetryczną. Eromenos był zawsze stroną podległą, więc nie był partnerem we właściwym tego słowa znaczeniu. Powinien się odwdzięczać godziwą służbą za to, że w takiej miłosnej relacji staje się mądry ${ }^{30}$. Wśród tych usług mogły znajdować się również elementy zmysłowe, o ile chłopak nie pozwalał erastesowi na seks analny i oralny, oraz nie odczuwał przyjemności ze współżycia, czyli nie upodabniał się do kobiety ${ }^{31}$. Te zachowania były uważane za sprowadzające hańbę. Same sugestie co do pełnienia biernej roli, zwłaszcza ochoczego, w homoseksualnych związkach mężczyzn były obrazą. Przykład takiej mentalności znajdujemy w historii Periandra z Ambrakii, który zapytał swego eromenosa, czy przypadkiem nie jest w ciąży, i za tę obelgę został zabity ${ }^{32}$.

By pozyskać względy młodzieńców, mężczyźni mieli zwyczaj wręczania im prezentów. Były to dary podkreślające tradycyjnie rozumianą męskość: konie, psy myśliwskie, koguty; te ostatnie były dla Greków symbolem potencji i waleczności. Ze względu na podobieństwo tych praktyk do prostytucji Arystofanes do niej właśnie porównał paiderastię: „A bo się wstydzą jawnie brać pieniądze. To samo draństwo, tylko nazwa inna"33.

Xenophon, Memorabilia Socratis 1, 2, 29 (Ksenofont, Pisma, 34).

Phaedrus 231 A-B (Platon, Dialogi, 20-21). Dywagacje na temat seksualnej orientacji Sokratesa należy uznać za osobliwe. Wiemy bowiem, że zanim się ożenił i miał dzieci, swój apetyt erotyczny zaspokajał bez hybris, to znaczy bez gwałtu i naruszania związków małżeńskich; por. Arystoksenos, fr. 55, na który powołuje się Dover, Homoseksualizm, 187.

Plato, Symposium 217 A - 219 D (Platon, Dialogi, 116-119).

Plato, Res publica 403 B (Platon, Państwo, 101).

Lucianus Samosatensis, Amores, 51 (Lukian, Dialogi, 44).

Plato, Euthydemus 282 B (Platon, Eutydem, 101).

Teoretycznie dopuszczalny był stosunek między udami młodszego partnera, choć zabytki plastyczne prezentują zgoła bogatsze wersje seksualności między osobami tej samej płci.

Plutarchus, Amatorius, 23 (Plutarch, Moralia, 311). Według Anthony’ego Birley’a, na którego powołuje się John B. Burns („The 'Dog' [Keleb] in Ancient Israel”, 6, przyp. 7), przyczyną samobójstwa Antinousa było osiągnięcie przez chłopaka wieku, w którym utrzymywanie intymnych relacji z mężczyzną było uważane za wykraczające poza ramy paiderastii, co mogło sprowadzić na młodego Greka hańbę.

Aristophanes, Plutos, 158-159 (Arystofanes, Komedie, II, 416-417). 
Zdawano sobie również sprawę z tego, że w gimnazjonach i instytucjach, gdzie młodzi mężczyźni ćwiczyli nago, bywali również nie tyle miłośnicy sportu, co męskich ciał lub podglądacze. Ślady takich problemów - bo było to problemem dla samych Greków - znajdujemy między innymi w komedii attyckiej. Przywołany wyżej Arystofanes chwali młodzieńców, którzy umieją zachować się tak, by siadając nie odsłaniać części intymnych, a wstając zacierają ślady własnych pośladków. Zauważył bowiem, że męska młodzież, świadoma swej ponętności, skłonna jest do uwodzenia wpływowych i majętnych mężczyzn, a w konsekwencji popadania w zniewieściałość (w sensie przejmowania tradycyjnej roli kobiecej) ${ }^{34}$. Oczywiście są to ujęcia komiczne, wyolbrzymiające negatywne aspekty osób i wyśmiewanych sytuacji. Nie narodziły się jednak bez powodu, zwłaszcza że w ich kontekstach pojawiają się konkretne imiona postaci historycznych. Przyczyną jest przekonanie, że pragnienie zapanowania nad partnerem lub kochanie jedynie piękna ciała (z pominięciem innych aspektów osoby) sprowadzały hańbę $e^{35}$. Paiderastia jawi się więc jako forma sprzyjająca wytworzeniu się zależności seksualnej młodego mężczyzny od dorosłego obywatela, zależności sankcjonowanej tradycją i prawem. Podejmując próbę jej interpretacji, trzeba docenić nie kategorie związane z płcią biologiczną, lecz z jej społeczną rolą ${ }^{36}$. Eros w paiderastii kształtował bowiem duszę eromenosa i określał jego postawę obywatelską, zaś elementy zmysłowe były sposobem korzystania z przyjemności przez erastesa, częstokroć natarczywego i przekonującego do siebie prezentami, niekiedy drogimi. Tak więc choć Grecy dość swobodnie korzystali $z$ rozkoszy zmysłowych także ze swoimi eromenosami, nie można widzieć tu prostego odniesienia do homoseksualnego seksu. Owe czasy nie znały jeszcze pojęcia oznaczającego współżycie mężczyzn (å $\rho \varepsilon v o \mu ı \xi i \alpha)$. Pojawiło się ono dopiero u Sekstusa Empiryka (II-III w. po Chr.) w jego opisie zwyczajów Persów i Germanów ${ }^{37}$.

\section{Szczególny przypadek kobiet}

Mamy niewiele świadectw dotyczących homoseksualnych relacji wśród kobiet. Najbardziej znanym świadectwem z epoki archaicznej są aluzje do relacji miłosnych Safony (VII-VI w. przed Chr.). Wiemy, że była arystokratką i prowadziła rodzaj wspólnoty (z grecka thiasos) dla dziewic. Była to zapewne jedna z uznanych grup religijnych przygotowujących młode kobiety do roli żony ${ }^{38}$ albo - co wydaje się bliższe prawdy - typ prywatnego stowarzyszenia kobiet zjednoczonych wokół tajemnicy re-

\footnotetext{
Aristophanes, Nubes 973-984 (Arystofanes, Komedie, I, 227-228).

Np. Xenophon, Convivium 8, 23.26 (Ksenofont, Pisma, 289-290).

Winkler, The Constraints of Desire; za nim Lengauer, „Od haniebnego występku”, 322.

Lengauer, „Od haniebnego występku”, 315-316.

Np. Calame, Choruses of Young Women, 212.
} 
ligijnej lub wokół charyzmatu liderki ${ }^{39}$. Charakter thiasos określa kontekst powstania i wpływa na interpretację utworów Safony. Trzeba zauważyć również, że pośród jej utworów są i takie, które napisała językiem analogicznym do tego, którym posługiwali się mężczyźni wobec swoich ukochanych chłopców w ramach paiderastii ${ }^{40}$. Mimo to trudno przyjąć, by jej poezja była wyznaniem o charakterze wyłącznie osobistym. Raczej wykonywała ją wraz ze swoimi wychowankami publicznie, zapewne z okazji formalnych lub prywatnych uroczystości.

Próby interpretacji niektórych utworów Safony w kluczu homoseksualnym podejmowano od starożytności. Pierwszy i zarazem najbardziej znany z jej utworów to oda do Afrodyty, w którym podmiot liryczny, najpewniej sama Safona (choć można przyjąć również inne możliwości), żali się bogini na miłosne udręki w duszy. Zaklinana Afrodyta odpowiada pytaniem, kim jest ukochana (1, 19: ją, choćby bezwolną $\left(1,24\right.$ : $\left.\kappa \omega u ̉ \kappa ~ \varepsilon ̇ \theta \varepsilon ́ \lambda o เ \sigma \alpha^{41}\right)$, poddać swej mocy. Niewątpliwie utwór ten podkreśla moc Erosa (jest to więc erotikon). Nie jest jednak jasne, co ma się stać z dziewczyną: czy swoim uczuciem będzie ścigać Safonę, czy zwróci się ku innej kobiecie $e^{42}$. Być może rację ma André Lardinois, który dostrzega tu zamierzone podkreślenie wszechwładzy miłości i tego, że ufać jej nie można. W tym świetle utwór nabiera cech tak ogólnych, że trzeba w nim widzieć szeroki opis siły miłości i przyjaźni ${ }^{43}$.

Inne poezje Safony są bardziej enigmatyczne. Przykładem jest oda „patograficzna" (fragment 31). Wachlarz jej interpretacji waha się od miłości autorki do zakochanego w innej młodzieńca po jej wzdychanie do dziewczyny, w którą wpatrzony jest oblubieniec. Próby odnalezienia w utworze śladów homoseksualności za pomocą analiz psychologicznych okazują się złudne, ponieważ wykazano w nim konwencjonalny charakter literacki wzorowany na Homerze ${ }^{44}$. Jeszcze bardziej niejasne są przywoływane w kontekście możliwej homoseksualności Safony utwory zawierające opisy jej rozstań: fragment 16 nosi echa tęsknoty za piękną Anaktorią, która opuściła już saficki thiasos, zaś fragment 94 to pieśń wspominająca pożegnanie z nieznaną z imienia wychowanką. Podtrzymać zatem należy ostrożną opinię, że w zachowanych utworach poetki nie pojawia się nic, co dałoby się zinterpretować jako echo podjętego przez nią współżycia, chociaż niewątpliwie są to dzieła pełne żarliwego

39

40

Np. Stehle, Performance and Gender, 265-270.

Dover, Homoseksualizm, 211.

Tekst jest krytycznie niepewny. Mimo to poprawka przyjęta w wydaniu, na którym opiera się komentarz Jerzego Danielewicza (Liryka grecka, 137), wydaje się uzasadniona.

2 Trudno bowiem uznać za akceptowalną w epoce archaicznej inicjatywę kobiety w związku z mężczyzną. Inaczej było w epoce cesarskiej; Plutarch Dialog o miłości erotycznej skomponuje odnosząc się do mitu o Alkestis i nakaże Ismenodorze ubiegać się o względy Bakchona.

Lardinois, „Lesbian Sappho Revisited”, 27.

Danielewicz, Liryka grecka, 161. 
uczucia $^{45}$. W konsekwencji na tej podstawie nie można potwierdzić istnienia zwyczajowo lub prawnie usankcjonowanych związków miłosnych kobiet ${ }^{46}$.

Status kobiet na Lesbos w świetle tradycji attyckiej był wyjątkowy. Demokracja ateńska nie wydała ani jednej kobiety, która mogłaby się równać z Safoną. Samodzielność mieszkanek tej wyspy wyrażała się także w przeprowadzaniu konkursów piękności kobiet dla kobiet ${ }^{47}$. Ze wzmianek Plutarcha ${ }^{48}$ wiemy, że w okresie Cesarstwa Spartanki wchodziły z młodymi kobietami w relacje miłosne, co zinterpretował on przez analogię do ateńskich zwyczajów panujących między mężczyznami ${ }^{49}$. Być może zatem opinie o seksualnych relacjach Safony z jej wychowankami trzeba uznać za ślad niezrozumienia tradycji pielęgnowanych w safickim thiasos oraz za owoc skojarzeń $\mathrm{z}$ ateńską paiderastią. Jeszcze później zaś wpływ reputacji Safony sprawil, że każdą poetkę (np. Korynnę) kierującą wspólnotą dziewcząt uznawano za wchodzącą $\mathrm{z}$ nimi w relacje seksualn $\mathrm{e}^{50}$. Z kolei z pragnienia umieszczenia Safony w sferze określonej tradycyjną rolą kobiet płyną próby dobrania jej męża (miałby to być Kerkylas

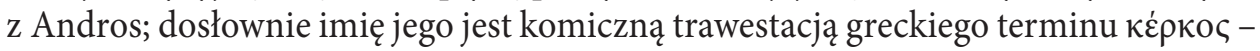
prącie, Adros zaś to dopełniacz od greckiego ảví $\rho$ - mężczyzna), o czym jednak nie mamy wystarczająco wiarygodnego przekazu.

Powyższe spostrzeżenia trzeba uzupełnić o inne świadectwa. Wśród nich pierwsza jest poezja Alkmana, mniej więcej współczesnego Safonie poety doryckiego. Utwór w edycjach jego dzieł oznaczany numerem jeden (gatunkowo jest to partheneion, dzieło opiewające dziewicę) wspomina o grupie kobiet poświęcających się muzyce i tańcom. Opisując relację między nimi, poeta używa terminologii, którą ówcześni mężczyźni stosowali do wyrażenia homoerotycznych pasji, przede wszystkim paiderastycznych. Zauważają to expressis verbis już scholia do Teokryta

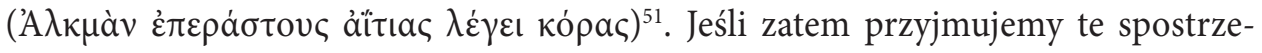
żenia za słuszne, wówczas ten partheneion Alkmana staje się wręcz epithalamion, pieśnią weselną wyśpiewywaną na cześć zawarcia związku dwóch kobiet, Hagesichory i Agido. Formalny lub nie charakter tej relacji jest już dalszym problemem ${ }^{52}$.

45 Tezy o zaistnieniu w życiu Safony takich związków zawierają wprost późniejsze testimonia z okresu hellenistycznego i Cesarstwa; Lardinois, „Lesbian Sappho Revisited”, 21-25.

46 Tak we fragmencie 213 Gorgo (prawdopodobnie sama poetka) kocha inną kobietę. Według Gentilego (Poetry and Its Public, 78) jest to świadectwo homoseksualnego małżeństwa. Koncepcję tę słusznie krytykuje Claude Calame (Choruses of Young Women, 213, przyp. 23), zauważając, że Safona stosuje tu aparat pojęciowy opisujący bliską przyjaźń Orestesa i jego szwagra Pyladesa.

47 Alcaeus, fr. 130b, 16-20 (Danielewicz, Liryka starożytnej Grecji, 212); Żok - Lisiak, „Początki refleksji teoretycznej o homoseksualizmie", 29-30.

48 Plutarchus, Lycurgus 18, 9.

49 Lardinois, „Lesbian Sappho Revisited”, 15.

50 Np. Flavius Philostratus, Vita Apollonii 1, 30 (Flawiusz Filostratus, Żywot, 72).

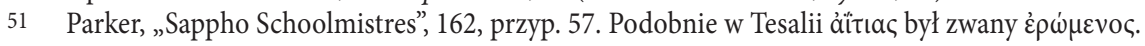

52 André Lardinois („Lesbian Sappho Revisited”, 16), powołując się na Bruno Gentilego (Poetry and Its Public, 72). Danielewicz (Liryka grecka, 68) twierdzi, że mimo obszernej literatury przedmiotu, nie jest możliwe ustalenie relacji między bohaterkami fragmentu 1. 
Jednakże Eva Cantarella uważa, że Alkman używa tu słownictwa dotyczącego piękna i erotyki w sensie ogólnym ${ }^{53}$. Potwierdza to uwagami na temat języka utworów oznaczonych numerami 26 i 34, w których opisana miłość dziewczęcia nie musi być skierowana ku kobiecie. Wieloznaczność fragmentu 26 dopuszcza jego interpretację jako opis skutków działania Erosa heteroseksualnego, a fragmentu 34 nawet jako symbolicznej miłości samego poety do struny, przy której drżeniu śpiewa ${ }^{54}$. By dostrzec w nich ewidentne ślady homoseksualności, potrzeba założeń, które z kolei pozostają w sferze hipotez ${ }^{55}$.

Nie oznacza to, że Alkman nie zaobserwował miłości kobiety do kobiety. Znaczącym świadectwem w tym zakresie jest fragment 3. Oto piękna przewodniczka chóru imieniem Astymelojsa przebiega wśród ludzi, tańcząc. Patrzą na nią z podziwem mężczyźni i kobiety, zadając sobie pytanie, czy mogłaby ich pokochać. Poeta celebruje jej piękno, podkreślając pragnienie zjednoczenia z nim. Astymelojsa jest bowiem słodka $(3,63)$, w jej obecności pożądanie obezwładnia widzów $(3,62)$, wreszcie staje się ucieleśnieniem piękna, budząc „westchnienia powszechne” (werset 74 zawiera stwierdzenie, że jest ukochaną ludu: $\mu \dot{\lambda} \lambda \eta \mu \alpha$ $\delta \dot{\alpha} \mu \omega \iota)$ i z którą sam chór dziewcząt chce nawiązać relację, padając jej do stóp niczym błagalnica (3, 79-81). Język erotyczny tego utworu jest jasny, a tekst zachowany na tyle dobrze, że mimo luk, wątpliwości interpretacyjne nie przybierają takiej skali, jaką widzieliśmy poprzednio. Jednakże proponowane jako wyłączne homoerotyczne interpretacje pieśni bazują na zbyt kruchych podstawach ${ }^{56}$. Tłum i chór zlewają się bowiem w jeden głos na cześć piękna choragis. Jeśli działała w ramach kobiecej paidei jako wzór dla młodych kobiet z chóru, nie musiało to oznaczać korzystania z rozkoszy erotycznej. Możliwe rozwiązania tych zagadnień pozostają jeszcze w obszarze przyszłych szczegółowych badań.

Nieco inne nawiązania erotyczne znajdujemy u jońskiego poety Anakreonta (VI-V w. przed Chr.). Ważny i zarazem sugestywny jest utwór 13. Oto starzejący się już autor został trafiony piłką złotowłosego Erosa (symbol pożądania) i wzdycha do pewnego dziewczęcia z Lesbos (czy szedł w konkury do samej Safony, po-

53 Niejasność interpretacji fragmentu 1 potwierdza nasza niewiedza na temat kolejnej bohaterki utworu, Ajnesimbroty, która ma władzę nad chórem i bohaterkami, ale nie wiadomo, jakiego charakteru jest to władza. Trudno widzieć tu również echa analogiczne do ateńskiej paiderastii. Wszystkie zastrzeżenia w: Lardinois, „Lesbian Sappho Revisited”, 19-20.

54 Lardinois, „Lesbian Sappho Revisited”, 16.

55 Dotyczy to także utworów 59a i b. Jeśli fragment 59a był przeznaczony do śpiewania przez chór kobiet i był zaadresowany również do kobiety, co nie jest wcale pewne, mógłby być śladem kobiecej homoseksualności. Fragment 59b, który koncentruje się wokół złotowłosej Megalostraty, posiadaczki daru Muz (prawdopodobnie chodzi o śpiew i taniec), w zaginionej części mógł wspominać o jej pożądaniu. Obie hipotezy są dziś de facto nie do udowodnienia. Trzeba jednak wspomnieć istnienie przekazu Atenajosa, który utrzymuje, że fragment 59a opowiada o miłości samego poety do Megalostraty z powodu jej wielkiego talentu muzycznego; por. Lardinois, „Lesbian Sappho Revisited”, 16. 
zostanie dla nas zagadką). Ta jednak, rozglądając się, rozdziawia usta szukając kogoś innego:

\author{
[...] Lecz ona - Lesbos \\ pięknego córa - spogląda wyniośle \\ na mą siwiznę; gdzie indziej \\ patrząc rozdziawia usta ${ }^{57}$.
}

Temat jest dość banalny, lecz został ubrany w dzieło kunsztowne dzięki aluzyjności, autoironii i dowcipowi. Gramatyka tekstu niewiele nam pomoże w jego interpretacji, ponieważ utwór jest żartem o cechach arystofanejskich: finał rozjaśnia właściwe znaczenie żartu. Pierwszym elementem jest sam poeta: oto poniósł klęskę w zalotach. Możliwe, że ratuje właśnie własną reputację kochanka ${ }^{58}$ : nie z powodu wieku został odrzucony, lecz miłosnych preferencji ukochanej, dla niego niedostępnej, bo wiążącej się z kobietami ${ }^{59}$. Jednak ostatecznie nie dowiemy się, czy piękność z Lesbos zamiast siwego poety wyglądała innego, czy wyczekiwała na kobietę, a być może wzdychała do innych włosów ${ }^{60}$. Utwór jest zatem celowo wieloznaczny, a zamieszczone tu interpretacje jednymi z możliwych ${ }^{61}$.

\title{
3. Homoerotyczne relacje między dorosłymi i rówieśnikami
}

Pomimo powyższej zamieszczonych świadectw, Grecy w znakomitej większości odrzucali seksualne związki między kobietami. Popularny stereotyp mówił, że kobieta nie powinna odczuwać przyjemności ze współżycia. Eros kobiety poważanej w społeczeństwie musiał być poddany ograniczeniom, które nie dotyczyły mężczyzn poza jednym wyjątkiem: brak przyjemności eromenosa w ramach paiderastii czynił stosunek z erastesem dopuszczalnym. Wejście w relację homoseksualną dwóch kobiet od-

\footnotetext{
57 Przekład Danielewicz, Liryka starożytnej Grecji, 249.

58 W dorobku Anakreonta znajduje się utwór (PMG 417) do dziewczyny, która odrzuciła jego zaloty jak nieujarzmione źrebię. Autor wykorzystuje tu popularny język erotyki, powszechnie bowiem porównywano kobiety do źrebiąt/klaczy.

59 Już u Homera kobiety z Lesbos uchodziły za najpiękniejsze wśród Greczynek (Il. 9, 129-130). Być może jak pisze Danielewicz (Liryka grecka, 306) - argument etniczny ma podkreślić, że wybranka poety była świadoma własnej wartości lub wręcz zarozumiała.

60 Czasownik $\lambda \varepsilon \sigma \beta ı \dot{\alpha} \zeta \varepsilon ı v$ oznaczał fellare; np. Łuka, „Nie tylko Gaius”, 96, przyp. 9. Nie ma jednak pewności, że w czasach Anakreonta funkcjonował stereotyp właściwy komediopisarzom, że kobiety z Lesbos specjalizują się w seksie oralnym i bywają prostytutkami. Liczne literackie świadectwa na ten temat zestawiła Komornicka, „A la suite de la lecture La Ragazza di Lesbo”, 37-41.

61 Danielewicz, Liryka grecka, 302-304.
} 
rzucano, interpretując ją jako skoncentrowaną na przyjemności. Przyczyny takiego podejścia były kulturowe.

Zachowane źródła potwierdzają istnienie związków miłosnych między dorosłymi mężczyznami. Nie wpisują się one w paiderastię. Już w Iliadzie zawarte są aluzje, które wskazują na miłość między Achillesem i Patroklosem oraz Telemachem i Peisistratosem ${ }^{62}$ : płacz, tęsknota i bezsenność, a także wspólne łoże to toposy wątków miłosnych. Reinterpretując w tym kluczu wojnę trojańską, Eubulos szyderczo zauważa, że wojsko greckie nie korzystało z usług heter i ostatecznie wróciło „do domów z zadkami bardziej rozwalonymi niż bramy, które zdobyli”' ${ }^{3}$. Z epoki klasycznej znana jest anegdota z życia Eurypidesa, którego kochankiem był piękny i już dojrzały Agaton: „Kiedy Eurypides w czasie uczty obejmował i całował pięknego Agatona, który wówczas miał już brodę, Archelaos powiedział do przyjaciół: «Nie dziwcie się: w przypadku ludzi pięknych piękna jest również jesień»"64. W Beocji czczono grób homoseksualnego towarzysza Heraklesa, Iolaosa, przy którym pary kochanków składali sobie obietnice wierności ${ }^{65}$. Wymienić trzeba także, jako paralele antropologiczne, niektóre mity, w których treści zawarte są wzmianki o związkach homoseksualnych między ludźmi dojrzałymi (np. o Orfeuszu, który po utracie Eurydyki wiązał się z mężczyznami, oraz o Dafne, która w oczach starającego się o jej rękę Leukipposa preferowała współżycie z kobietami). Liczne świadectwa ikonograficzne przedstawiają także pary homoseksualne mężczyzn, w tym oddających się różnym zabawom o charakterze seksualnym, w tym stosunkom analnym. Partnerzy bywają przedstawiani jako mniej więcej rówieśnicy, na innych z kolei zabytkach prezentujących mężczyzn w różnym wieku młodszy bywa stroną aktywną. Tego typu zabytki nie są li tylko śladem indywidualnych i starannie skrywanych upodobań klienta. Zamówione naczynia były raczej używane przy nadarzających się okazjach, nie budząc sprzeciwu. Także artysta musiał być zapoznany z tematyką, a ta nie mogła wywoływać u niego sprzeciwu czy szoku ${ }^{66}$.

Wydaje się jednak, że takie związki nie wpisywały się w standardy życia obywatelskiego. Wspomnianych wyżej Achillesa i Patroklosa Platon w Uczcie zinterpretował w kluczu podyktowanym paiderastią, kontynuując zresztą dyskusję na ten temat prowadzoną od Myrmidonów Ajschylosa ${ }^{67}$. Jak zaznacza W. Lengauer, również przedstawienia Tyranobójców ateńskich, chociaż byli w podobnym wieku, dostosowano się do wymogów paiderastii. Aristogejtona zatem przedstawiano z brodą, a Harmodiosa z gładkim podbródkiem. W ich osobach ateńska paiderastia zyskała

\footnotetext{
62 Cantarella, Selon la nature, 23-28; Laguna-Mariscal - Sanz-Morales, „Was the Relationship between Achilles and Patroclus Homoerotic?", 120-123.

63 Cyt. za Dover, Homoseksualizm, 165.

64 Plutarch, Powiedzenia królów i wodzów, 51.

65 Lengauer, „Od haniebnego występku”, 318-328.

66 Taki wniosek wyciąga Lengauer, „Eros, polis, obywatel”, 132.

67 Symposium, 180 A-B (Platon, Dialogi, 80-81); Platon, Biesiada, 53-58.
} 
wielkich patronów, historycznie istniejących obywateli, którzy mogli stać się wzorem nie tyle ze względu na wyeliminowanie tyrana (co zresztą miało miejsce później), lecz trwałą i piękną miłość ${ }^{68}$.

Mimo to obecność związków homoseksualnych w Grecji zdaje się nie budzić większego zainteresowania ani kontrowersji. Dwa czynniki powodowały jednak sprzeciw. Pierwszym z nich był czysto biologiczny aspekt, gdyż homoseksualne współżycie nie niesie ze sobą zrodzenia nowych pokolen' ${ }^{69}$. Drugi zaś to obowiązek spoczywający na każdym Greku. Było to podjęcie tradycyjnej męskiej roli w społeczeństwie, którą to rolę miała cechować cnota umiaru ( $\sigma \omega \varphi \rho o v \varepsilon i ̃)$ ). Sumaryczne odniesienie do elementów jej przeciwnych znajdujemy u Arystofanesa ${ }^{70}$. Komediopisarz wymienia jednym tchem: chłopcy, dziewczęta, jedzenie, picie, gra w kości i śmiech, a kończy znamiennym „Jaką wartość ma życie bez tego wszystkiego?” Odwracając to wyliczenie dostrzegamy elementy, które uchodziły ówcześnie za zagrażające cnotom obywatelskim. W aluzji do chłopców trzeba widzieć brak powściągliwości i opanowania w zażywaniu rozkoszy, tu ukierunkowanej homoerotycznie ${ }^{71}$.

Oskarżenia o niektóre praktyki homoseksualne służyły do zneutralizowania politycznych oponentów. Najsłynniejsza jest bodaj wspomniana wyżej sprawa Timarchosa, którego Ajschynes oskarżył o męską prostytucję, stręczycielstwo wolno urodzonych kobiet i chłopców, a także sprowadzenie wolnych Ateńczyków do roli niewolników (w kontekście seksualnym). Takie przestępstwa karano karą główną ${ }^{72}$. Przywołana wyżej w kontekście paiderastii historia Periandra z Abrakii potwierdza, że oskarżenia o pełnienie roli biernej w akcie homoseksualnym były obraźliwe. Podobną treść, już poza kontekstem wychowania, zauważyć można w jednej z sielanek Teokryta, w której poeta żartuje z seksualnej relacji pasterza kóz z pasterzem owiec:

\footnotetext{
Komatas:

Pomnisz, jakem cię dosiadł? Ze zgrzytaniem zębów

I tęgo kuprem wiercąc trzymałeś się dębu.

Lakon:

Tego jakoś nie pomnę, ale jak cię spętał

Eumaras i wyćwiczył, dobrze to pamiętam ${ }^{73}$.
}

Widzimy po raz kolejny, że oskarżenie o czerpanie przyjemności z pełnienia roli biernej służyło polemikom i wykpiwaniu oponentów. Partner aktywny w takim związku nie miał powodów do okazywania wstydu.

\footnotetext{
68 Lengauer, „Eros, polis, obywatel”, 132.

69 Np. Lucianus Samosatensis, Amores 19 (Lukian, Dialogi, 31).

70 Aristophanes, Nubes 1071-1074 (Arystofanes, Komedie, I, 231).

71 Foucault, Historia seksualności, 217.

72 Dover, Homoseksualizm, 31-149.

73 Theocritus, Viatores seu Bucoliastae 116-119 (Teokryt, Sielanki, 51).
} 
W kontekst pogardy skierowanej ku partnerowi biernemu wpisuje się również element przemocy. Zauważyła go E.C. Keuls, pisząc książkę o władztwie fallusa. Penetracja mężczyzny przez partnera tej samej płci była jednym z elementów potwierdzenia nadrzędnej pozycji napastnika. Mogło się to wydarzyć wobec obcokrajowców, niewolników i tych, którzy nie posiadali praw obywatelskich ${ }^{74}$. Potwierdza to zachowany materiał ikonograficzny. Carola Reinsberg ${ }^{75}$ zamieszcza opis malowidła na wazie sporządzonej po wygraniu przez Helladę bitwy nad Eurymedonem (465 r. przed Chr.). Oto Grek grozi pokonanemu Persowi gwałtem analnym. Czynnik homoseksualny stał się więc ostatecznym argumentem odstraszającym i poniżającym przeciwną stronę konfliktu, choć nie były jedynie retorycznym popisem. Niektórzy bibliści przypuszczają, że są tłem izraelskiego przepisu zabraniającego składać w świątyni zapłaty psa (Pwt 23,19), czyli mężczyzny będącego bierną stroną we współżyciu homoseksualnym ${ }^{76}$.

W przypadku trwałego preferowania miłości z osobami tej samej płci dopuszczano możliwość pozostawania w stanie bezżennym (taką drogę wybrał Platon, choć nie można tej decyzji uznać za świadectwo wprost jego preferencji seksualnych, mimo że takie sugestie się pojawiają) lub wybór relacji z osobą tej samej płci ${ }^{77}$. Jasne było bowiem, że niektóre osoby preferują relacje miłosne z osobami tej samej płci. Próbowano wyjaśnić także to zjawisko.

\section{Konteksty przyczynowe homoseksualności}

Boskie działanie Erosa wiąże się z przyjemnością. Grecy zostawili nam szereg tekstów, z których związki homoerotyczne wyłaniają się jako rozkoszne dary Afrody$\operatorname{ty}^{78}$. Według Platona są szałem Erosa, najlepszym ze wszystkich ${ }^{79}$. Pod jego wpływem był działający w okresie archaicznym Teognis (VI w. przed Chr.). Druga księga jego liryków to utwory opiewające miłość do chłopca, którego piękno dla poety było darem bogini miłości. W epoce klasycznej Ksenofont przytacza wypowiedź Izokratesa, który stwierdził, że miłość mężczyzny do chłopca należy do dziedziny Afrodyty i daje taką przyjemność, że „niełatwo znaleźć nadzieje i zajęcia rozkoszniejsze

74 Burns, „The 'Dog' (Keleb) in Ancient Israel”, 6. Autor ten uznaje, że również młodzi ludzie mogli być penetrowani, z czym nie sposób bez zastrzeżeń się zgodzić. Foucault (Historia seksualności, 253) zaznacza, że relacje społeczne i seksualne między mężczyznami były wręcz izomorficzne.

Reinsberg, Obyczaje seksualne, 133, ilustracja 98a-b.

76 Tak np. wspomniany wyżej Burns.

77 Lengauer, „Eros among citizens”, 74.

78 Za wynalazcę homoseksualności uchodził ojciec Edypa, Lajos, który uwiódł Chryzypa, syna Pelopsa. Doprowadzenie do śmierci kochanka, a nie sama pasja erotyczna była winą i przyczyną klątwy rodu Labdakidów.

Np. Plato, Phaedrus 265 B (Platon, Dialogi, 54). 


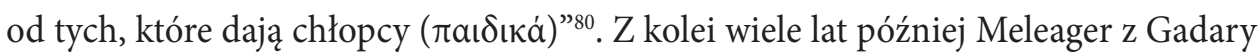
(I w. przed Chr.), mając wybrać między kobietą i chłopcem, skonsultuje się poetycko z Afrodytą i stwierdzi, że zwycięzcą w tym pojedynku jest chłopak ${ }^{81}$.

Grecy nie sankcjonowali wyborów seksualnych prawem ani ludzkim, ani boskim.

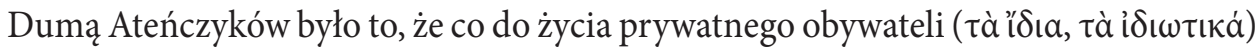
byli wyrozumiali. Regulowali tylko sprawy publiczne ( $\tau \grave{\alpha} \delta \eta \mu o \sigma i ́ \alpha)$. Do nich jednak należała sfera Erosa ${ }^{82}$. Pod kontrolą polis były niektóre sprawy seksualne (w tym nakaz współżycia trzy razy w tygodniu z żoną, która była dziedziczką), a także domy publiczne, w których pracowali także mężczyźni. Ateny pobierały podatek od pro-

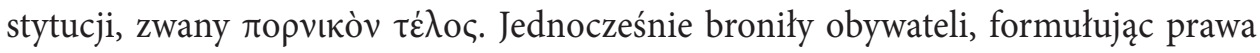
przeciwko stręczycielom i gwałcicielom, ich ofiary uwalniając od winy, choć zgwałconych nie uwalniały od konsekwencji przewidzianych dla współżyjących w sposób nieakceptowany przez polis (w tym zakazu obejmowania urzędów państwowych, jak w przypadku sprawy Timarchosa ${ }^{83}$. Co jest osobliwe, prawo chroniło także zgwałconych niewolników ${ }^{84}$. Mężczyzna mógł zatem utrzymywać legalne relacje seksualne z osobami tej samej płci, była to kwestia jego decyzji, byleby podjętej w zgodzie z prawem i zwyczajem. Wybory miłosne podlegały bowiem takiej samej ocenie jak wszystkie inne aspekty życia obywatela ${ }^{85}$. Jeśli działalność erotyczna była niezgodna

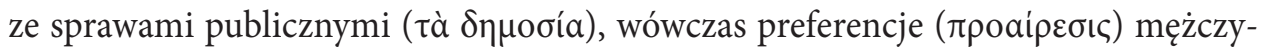

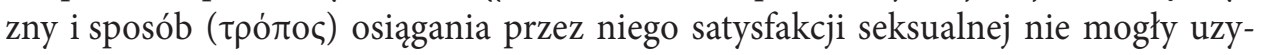
skać akceptacji. Eros nie miał bowiem bezwzględnej władzy nad obywatelem. Skoro nawet samej konieczności można było się przeciwstawić stanowczością, tym bardziej piękno ani zmysłowa przyjemność (ả $\varphi \rho o \delta$ เó́a) nie zmuszały do uległości ${ }^{86}$.

Skąd jednak płynie siła Erosa homoseksualnego? Również filozofowie zaobserwowali, że niektórzy preferują relacje miłosne z osobami własnej płci, które to relacje nie dają się zakwalifikować jako paiderastia. Pierwszą propozycją wyjaśnienia pragnienia dopełnienia $\mathrm{z}$ osobą tej samej płci jest ujęte $\mathrm{w}$ języku mitu ${ }^{87}$ opowiadanie Arystofanesa, zapisane przez Platona w $U_{c z c i e}{ }^{88}$. Według tego komediopisarza ludzie pierwotnie mieli istnieć jako istoty androginiczne: każdy posiadał na jednej głowie

\footnotetext{
80 Xenophon, Oeconomicus, 12 (Xenophon, Xenofonta Ekonomik, 52).

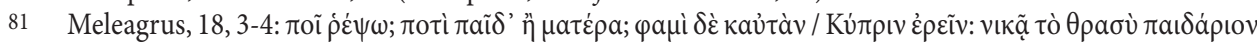
(Paton, The Greek Anthology, 4, 324).

82 Lengauer, „Eros, polis, obywatel”, 133; Nowak, „Uwagi o prostytucji w Atenach”, 330.

83 Dover, Homoseksualizm, 45-48; Nowak, „Uwagi o prostytucji w Atenach”, 335-336, 348. Według tej ostatniej prostytucją trudnili się młodzi mężczyźni, czasem nawet bardzo młodzi chłopcy.

84 Jakóbik, „Kryminalizacja”, 178-179.

85 Lengauer, „Eros, polis, obywatel”, 132.

86 Dover, Homoseksualizm, 46, 80-82.

87 Jest to mit o charakterze etiologicznym. Zob. Lamascus, The Poverty of Eros, 37-40; Dover („Aristophanes' Speech", 41-50) identyfikuje całą mowę Arystofanesa jako enkomion Erosa.

88 Trzeba tu zaznaczyć, że nie ma powodów, by odmówić Arystofanesowi jego autorstwa. Zob. Allen, The Dialogues of Plato, 31-32.
} 
dwie twarze, dwie pary rąk i dwie pary nóg, a także podwójne części płciowe. Ze względu na wielką siłę tych istot Dzeus postanowił je osłabić przez podzielenie tych istot na pół. Wskutek tego

kobiety odcięte od dawnej żeńskiej istoty nie bardzo dbają o mężczyzn, a więcej się interesują kobietami, i stąd się wywodzą trybadki (lesbijki). Ale ci, których od męskiego odcięto pnia, gonią za męskim rodzajem i już jako mali chłopcy lubią te kupony męskie mężczyzn ściskać na posłaniu. To są najwybitniejsze jednostki pomiędzy chłopcami i młodymi ludź$\mathrm{mi}$, to są najbardziej męskie natury ${ }^{89}$.

Oto opis pierwotnego stanu człowieka, psychologizująca obserwacja wyjaśniająca przyczyny, dla których potrzebuje on partnera, z którym mógłby stworzyć relację inną niż wszystkie ${ }^{90}$. Odnalezienie monogamicznego dopełnienia w drugim człowieku jest w rzeczywistości rozpoznaniem części pierwotnej istoty. Związek oparty

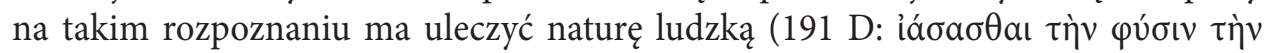
ảv $\theta \rho \omega \pi i ́ v \eta v)$. W ten sposób autor zaznacza, że jedynie tak rozumiana miłość przywraca pierwotną jedność temu, co wskutek rozdzielenia stało się obce. Jak w języku filozofii pisze Józef Lipiec, „» Ja« przenika w »ty«, »ty« jesteś we »mnie« i ze »mną«, jesteśmy dwiema stronami jednej podmiotowej substancji" "11. Co więcej, alegoria Arystofanesa podkreśla, że mężczyzna kochający mężczyznę w rzeczywistości kocha kogoś, kogo rozpoznaje się jako uzupełnienie własnej istoty. Komediopisarz nie dziwi się temu: „kochają przecież to, co do nich samych podobne" ${ }^{22}$. Takie jednostki uznaje za najwybitniejsze dzięki ich śmiałości, odwadze i specyficznie męskiemu zacięciu. Odrzuca zaś interpretacje widzące w takich związkach bezwstyd i bezczelność. Potęga takiego Erosa nie koncentruje się na rozkoszy i zmysłowej przyjemności (å $\varphi \rho o \delta ı \sigma i ́ a)^{93}$, choć pełni ona istotną funkcję w związkach oraz wiąże się z płodzeniem potomstwa ${ }^{94}$. Jednakże - jak pisze Artur Pacewicz - „poprzez koncentrację tylko na sferze zmysłowej, w której nie istnieją kryteria ograniczające i regulujące działanie człowieka, dochodzi do pojawienia się hubris oraz «gonienia za przyjemnością wbrew naturze»" ${ }^{\prime 5}$.

Rozstrzygnięcie problemu genezy preferencji osób tej samej płci w miłości proponuje również Arystoteles w swojej Etyce nikomachejskiej. O relacjach płciowych między mężczyznami pisze, że „skłonność do nich jest u jednych wrodzona, u in-

\footnotetext{
89 Plato, Symposium 189 C - 193 C (Platon, Dialogi, 89-93).

90 Nichols, Socrates on Friendship and Community, 47-52.

91 Lipiec, „Zaproszenie na ucztę”, 83.

92 Plato, Symposium 192 B (Platon, Dialogi, 92).

93 Cobb, Plato's Erotic Dialogues, 67-68.

94 Anderson, The Masks of Dionysios, 43-44.

95 Pacewicz, Hēdonē, 127.
} 
nych pochodzi z przyzwyczajenia, jak u tych, co od lat chłopięcych są zhańbieni”96. Należy znów zauważyć, że diagnoza ta nie obejmuje paiderastii, nie porusza również problemu winnego na przykład homoseksualnego gwałtu ${ }^{97}$. Podobnie jak w przypadku alegorii Arystofanesa, obserwujemy tu opis sytuacji, w których proporcjonalnie aktywne są obie strony, tworząc trwały związek ${ }^{98}$. Stagiryta wyraża przekonanie, że relacje homoseksualne należą do sfery miłosnej w jej zmysłowym aspekcie $\left(\tau \tilde{\omega} \nu \dot{\alpha} \varphi \rho o \delta\llcorner\sigma i ́ \omega v)^{99}\right.$. Pragnienie doznawania rozkoszy w takich związkach miałoby być powodowane naturą ( $\varphi v ́ \sigma \varepsilon ı)$, której bliżej nie doprecyzowuje ${ }^{100}$, względnie przy-

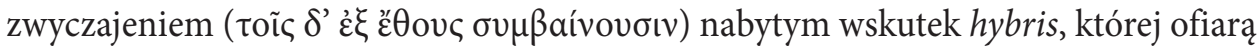

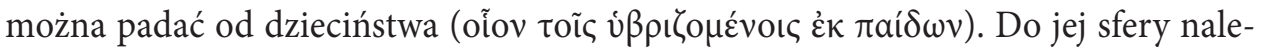
ży bowiem również przyjemność o charakterze nieuznawanym prawem i tradycją, w tym niektóre sposoby osiągania satysfakcji seksualnej. Z kontekstu kulturowego wynika, że nie chodzi tu o krytykę paiderastii ani roli aktywnej w takich związkach, lecz o podejmowanie kobiecej, czyli biernej roli. Tę zaś Arystoteles poddał ocenie etycznej, wprowadzając istotny kontekst: jeśli tak realizowane preferencje homoerotyczne wynikają z natury lub są skutkiem uprzednich nadużyć, obniża to ich krytyczną ocenę w świetle cnoty wstrzemięźliwości.

Zachował się również traktat Zagadnienia przyrodnicze przypisany Arystotelesowi, a w rzeczywistości wywodzący się z jego szkoły. Autor tego dzieła zainteresował się rolami we współżyciu homoseksualnym, o partnerze aktywnym wspominając jedynie pobieżnie ${ }^{101}$. Skoncentrował się natomiast na roli biernej, spekulując na temat przyczyn takich preferencji. Wyciągnął fantastyczny wniosek i pisał, że przyczyna tego stanu leży w zwyrodnieniu odbytu, bynajmniej z powodu podjętego współżycia analnego. Ono jest wtórne i wynika z uprzedniego zaniku cech męskich. Narząd ten, upodabniając się do części kobiecych, wymaga bodźców właściwych kobietom ${ }^{102}$. Jest to rzadki przykład spekulacji o charakterze anatomicznym i fizjologicznym. Autor w ten sposób kontynuuje myśl wyrażoną w Etyce nikomachejskiej i uzasadnia poprawność wniosku, że krytyka etyczna opiera się na nieakceptowanej społecznie biernej roli mężczyzny w akcie homoseksualnym.

\footnotetext{
96 Aristoteles, Ethica Nicomachaea 1148 B (Śremska, 219).

97 Bardziński, „Pojęcie hybris”, 42.

98 Należy pamiętać, że strony takiego związku mogły być związane prawnym małżeństwem, jak np. ateńscy Tyranobójcy. W ich przypadku początkiem konfliktu była próba uwiedzenia żonatego już Harmodiosa, jednocześnie związanego trwałą relacją miłosną z Aristogejtonem.

99 Lengauer, „Od haniebnego występku”, 319.

100 Można jednak, posługując się cytatem z jego Polityki, określić naturę jako „właściwość, jaką każdy twór osiąga u kresu swego powstawania" (Politika 1252 B [Arystoteles, Polityka, 6]).

101 Aristoteles, Problemata 879 B - 880 A (Arystoteles, Dzieła wszystkie, 531-532).

102 Dover, Homoseksualizm, 204-205. Istniało przekonanie, że część męskiego nasienia wytwarza się w odbycie. Według opinii ówczesnych, by znalazło ono ujście, potrzeba odpowiedniej stymulacji, jaką daje seks analny.
} 
Wieloaspektowość homoseksualności obejmuje najpierw paiderastię. Ujmowano ją jako wyjątkowo korzystną dla rozwoju osobowościowego, mimo braku równorzędności partnerów, a obecności elementów dominacji erastesa. Nie ogranicza się jednak do niej. Mniej lub bardziej trwałe związki osób tej samej płci były zjawiskiem znanym, obejmowały tak rówieśników, jak i osoby dorosłe w różnym wieku. Obywatel podlegał jednak pewnym normom społecznym ustanowionym przez polis, także w sferze związków międzyludzkich i osiągania satysfakcji płciowej. Zasady rządzące zachowaniami homoerotycznymi to przykład świadomego działania instytucji państwa i jego tradycji dla podtrzymania cnót obywatelskich, szczególnie powściągliwości, a także wyrugowania z życia politycznego obywateli, którzy owym cnotom nie hołdowali. W tym zakresie przeważa zatem aspekt aretologiczny.

Refleksja teoretyczna obejmowała również analizy przyczyn pragnienia tworzenia związków z osobami tej samej płci zamiast zawierania małżeństw lub podtrzymywania ich jako równoległych. Interpretowano je powszechnie jako przejawy sfery Afrodyty. W tym zakresie istnienie relacji homoerotycznych nie budziło kontrowersji, o ile cechowała je względna trwałość i zachowywanie zwyczajów określonych tradycją. Poza tymi ograniczeniami preferencje i sposoby realizacji miłosnych pasji zależały od decyzji mężczyzny. Filozofowie zaś, obserwując obecne u niektórych ludzi preferencje homoseksualne, podjęli próby wyjaśnienia ich przyczyn. Choć pojęcie orientacji seksualnej było im obce, czasami (zwłaszcza Platon i Arystoteles) treściowo dochodzą do bliskich jej idei.

Ówczesne tradycje widziały w homoseksualnym Erosie moc, której można się było przeciwstawiać, chcąc zachować ramy tradycji polis. Ocena etyczna rozkoszy płciowych zgodna była z tradycjami obyczajowymi polis. Słuszne jest zatem widzieć homoseksualność w skomplikowanym systemie greckich przekonań jako element życia kulturowego, narzucający obywatelom konieczność podjęcia utrwalonej społecznie roli płci.

\section{Bibliografia}

Allen, R.E., The Dialogues of Plato. II. The Symposium (New Haven, CT - London: Yale University Press 1991).

Anderson, D.E., The Masks of Dionysios. The Commentary of Plato's Symposium (Albany, NY: State University of New York Press 1993).

Aristoteles, Ethica Nicomachea (red. I. Bywater) (Oxford: Clarendon 1894); tł. D. Śremska: Arystoteles, Etyka nikomachejska (Warszawa: PWN 2012).

Arystofanes, Komedie (tł. K. Ławińska-Tyszkowska) (Biblioteka Antyczna; Warszawa: Prószyński i S-ka 2001-2003) I-II. 
Arystoteles, Polityka z dodaniem Pseudo-Arystotelesowskiej Ekonomiki (tł. i przyp. L. Piotrowicz; wstęp K. Grzybowski) (PWN: Warszawa 1964).

Arystoteles, Dzieła wszystkie (tł., wstępy i komentarze A. Paciorek - L. Regner - P. Siwek) (Warszawa: Wydawnictwo Naukowe PWN 1993) IV.

Bardziński, F., „Pojęcie hybris w kulturze i filozofii greckiej”, Ethics in Progress 7/2 (2016) 31-57.

Bethe, E., „Die dorische Knabenliebe. Ihre Ethik und ihre Idee”, Rheinisches Museum für Philologie 62 (1907) 438-475.

Burns, J.B., " The 'Dog' (Keleb) in Ancient Israel as a Symbol of Male Passivity and Perversion”, Journal of Religion and Society 2 (2000) 1-10, http://moses.creighton.edu/ JRS/2000/2000-6.pdf [dostęp: 21.10.10].

Calame, C., Choruses of Young Women in Ancient Greece, Their Morphology, Religious Role, and Social Function (Greek Studies, Interdisciplinary Approaches; Lanham, MD: Rowman \& Littlefield 2001).

Cantarella, E., Selon la nature, l'usage et la loi. La bisexualité dans le monde antique (Paris: La Découverte 1991).

Cobb, W.S., Plato's Erotic Dialogues (Albany, NY: State University of New York Press 1993).

Danielewicz, J. (oprac.), Liryka grecka. II. Melika (Warszawa - Poznań: PWN 1999).

Danielewicz, J. (oprac.), Liryka starożytnej Grecji (Warszawa - Poznań: PWN 1996).

Dover, K.J., „Aristophanes' Speech in Plato’s Symposium”, Journal of Hellenic Studies 86 (1966) 41-50.

Dover, K.J., Homoseksualizm grecki (Kraków: Homini 2004).

Flawiusz Filostratos, Żywot Apolloniusza z Tiany (tł. I. Kania) (Kraków: Oficyna Literacka 1997).

Foucault, M., Historia seksualności (Warszawa: Czytelnik 1995).

Gentili, B., Poetry and Its Public in Ancient Greece. From Homer to the Fifth Century (Baltimore, MD: John Hopkins University Press 1988).

Hubbard, T.H., Homosexuality in Greece and Rome. A Sourcebook of Basic Documents (Berkeley - Los Angeles, CA: University of California Press 2003).

Komornicka, A.M., „A la suite de la lecture La ragazza di Lesbo”, Quaderni Urbinati di Cultura Classica 21 (1976) 37-41.

Ksenofont, Pisma sokratyczne. Obrona Sokratesa, Wspomnienia o Sokratesie, Uczta (tł. L. Jachimowicz) (Biblioteka Klasyków Filozofii; Warszawa: PWN 1967).

Jakóbik, S., „Kryminalizacja kontaktów homoseksualnych w starożytnych Atenach”, Problemy nauk społecznych, humanistycznych, ekonomicznych: konteksty i wyzwania" (red. K. Pujer) (Wrocław: Exante 2017) 173-181.

Laguna-Mariscal, G. - Sanz-Morales M., „Was the Relationship between Achilles and Patroclus Homoerotic? The View of Apollonius Rhodius", Hermes 133/1 (2005) 120-123.

Lamascus, L.D., The Poverty of Eros in Plato's Symposium (London - New York: Bloomsbury Academics 2017).

Lardinois, A., „Lesbian Sappho and Sappho of Lesbos”, From Sappho to de Sade (red. J.N. Bremmer) (Moments in the History of Sexuality; London: Routledge 1989) 15-35.

Lardinois, A., „Lesbian Sappho Revisited”, Myths, Martyrs, and Modernity. Studies in the History of Religions in Honour of Jan N. Bremmer (red. J. Dijkstra - J. Kroesen - Y. Kuiper) (Leiden: Brill 2010) 13-30. 
Lengauer, W., „Eros Among Citizens”, Palamedes 1 (2006) 67-83.

Lengauer, W., „Eros, polis, obywatel”, Konteksty. Polska Sztuka Ludowa 58/1-2 (2004) 153-161.

Lengauer, W., „Od haniebnego występku do gender studies. Badania nad grecką paiderastia

w XX wieku", Przegląd Historyczny 98/3 (2007) 315-328.

Lipiec, J., „Zaproszenie na ucztę”, Nowa Krytyka 6 (1995) 67-85.

Ludwig, P.W., Eros and Polis. Desire and Community in Greek Political Theory (Cambridge: Cambridge University Press 2002).

Lukian, Dialogi (tł. W. Badyda) (Wrocław: Ossolineum 1966) III.

Łuka, A., „Nie tylko Gaius. Sensacyjne znaleziska za szafą”, Łódzkie Studia Teologiczne 27/2 (2018) 95-110.

Nichols, M.P., Socrates on Friendship and Community. Reflections on Plato's Symposium, Phaedrus, and Lysias (Cambridge: Cambridge University Press 2009).

Nissinen, M., Homoeroticism in the Biblical World. A Historical Perspective (Minneapolis, MN: Fortress Press 1998).

Nowak, M., „Uwagi o prostytucji w Atenach w V i IV wieku p.n.e., Przegląd Historyczny 98/3 (2007) 329-350.

Pacewicz, A., Hēdonē. Koncepcja przyjemności w filozofii Platona (Wrocław: Oficyna Naukowa PFF 2016).

Parker, H.N., „Sappho Schoolmistres”, Re-reading Sappho. Reception and Transmission (red. E. Greene) (Berkeley, CA - Los Angeles, CA - London: University of California Press 1996) 146-183.

Paton, W.R. (red.), The Greek Anthology with an English Translation (London: Heinemann 1926).

Plato, Symposium. Greek Text with Commentary by Kenneth J. Dover (Cambridge Greek and Latin Classics; Cambridge: Cambridge University Press 1980).

Platon, Biesiada (tł. i słowo towarzyszące E. Zwolski) (Biblioteka Principia, Stoicheia 1; Kraków: Secesja 1993).

Platon, Dialogi (tł. W. Witwicki) (Libri Mundi; Warszawa: Verum 1993).

Platon, Hippiasz Mniejszy, Hippiasz Większy, Eutydem (tł. W. Witwicki) (Biblioteka Europejska; Kęty: Antyk 2002).

Platon, Państwo (tł. W. Witwicki) (Biblioteka Europejska; Kęty: Antyk 2003).

Plutarch, Lycurgus, http://penelope.uchicago.edu/Thayer/E/Roman/Texts/Plutarch/ Lives/Lycurgus*.html [dostęp: 21.20.2020].

Plutarch, Moralia (wybór) (tł. Z. Abramowiczówna) (Warszawa: PWN 1977).

Plutarch, Powiedzenia królów i wodzów. Powiedzenia spartańskie (tł. K. Jażdżewska) (Biblioteka Antyczna; Warszawa: Prószyński i S-ka 2006).

Reinsberg, C., Obyczaje seksualne starożytnych Greków (tł. B. Wierzbicka) (Gdynia: Uraeus 1998).

Sergent, B., L’homosexualité dans la mythologie grecque (Paris: Payot 1984).

Sergent, B., L'homosexualité initiatique dans l'Europe ancienne (Bibliothèque historique; Paris: Payot \& Rivages 1986).

Sieradzan, J., „Bez paiderasteia nie ma paideia. Pedagogiczny aspekt pederastii starogreckiej”, IDEA - Studia nad struktura i rozwojem pojęć filozoficznych 21 (2009) 19-34.

Stehle, E., Performance and Gender in Ancient Greece. Nondramatic Poetry in its Setting (Princeton, NJ: Princeton University Press 1997). 


\section{HOMOSEKSUALNOŚĆ WEDŁUG STAROŻYTNYCH GREKÓW}

Teokryt, Sielanki (tł. A. Sandauer) (Warszawa: PIW 1973).

Winkler, J.J., The Constraints of Desire. The Anthropology of Sex and Gender in Ancient Greece (New York - London: Routledge 1990).

Xenophon, Xenofonta Ekonomik (tł. A. Bronikowski) (Poznań: Księgarnia Żupańskiego 1857). Żok, A. - Lisiak, H., „Początki refleksji teoretycznej o homoseksualizmie”, Poznańskie Zeszyty Humanistyczne 21 (2014) 27-31. 
